\title{
Profitability Study of Hibiscus sabdariffa L. Production around Wendo Genet District, Ethiopia
}

\author{
Tamirat Girma*, Muluken Philiphos and Shewaye Abera
}

Wondo Genet Agricultural Research Center, EIAR, P.O. Box: 198, Shashemene, Ethiopia

\begin{tabular}{|c|c|}
\hline Abstract & Article Information \\
\hline $\begin{array}{l}\text { Roselle (Hibiscus sabdariffa L.) belongs to the family Malvaceae, locally called "karkade", is an } \\
\text { important annual crop grown successfully in tropical and sub-tropical climates. It takes five } \\
\text { months from planting to harvesting. This study aims to examine financial feasibility and to } \\
\text { determine associated costs and benefits from the production of Hibiscus sabdariffa at Wondo } \\
\text { Genet. Two varieties of Hibiscus sabdariffa (WG-Hibiscus-Jamaican and WG-Hibiscus-Sudan) } \\
\text { was planted on an area of } 100 \mathrm{~m}^{2} \text { on experimental field with two replications using direct } \\
\text { sawing on field and seedling preparation on nursery for determination of costs and returns. } \\
\text { The spacing between plants and between rows was } 60 \mathrm{~cm}(60 \mathrm{~cm} \text { x } 60 \mathrm{~cm} \text { ). Simple cost } \\
\text { accounting method was employed to examine cost benefit of the plant. Net benefit and BCR of } \\
\text { hibiscus production was used to determine profitability. The result shows that Production cost } \\
\text { of Sudan type hibiscus is almost similar to Jamaican type except harvesting and post } \\
\text { harvesting management cost difference caused due to yield difference. However the } \\
\text { production of Sudan hibiscus is more profitable both by direct sawing and preparing seedlings } \\
\text { on nursery; the study also revealed that producing both type of hibiscus for calyx by direct } \\
\text { sawing is more profitable than using seedling preparation on nursery. Generally the study } \\
\text { shows production of both type of Hibiscus sabdariffa at wondogenet is profitable. } \\
\text { Copyright@2014 STAR Journal. All Rights Reserved. }\end{array}$ & $\begin{array}{l}\text { Article History: } \\
\text { Received : 21-10-2014 } \\
\text { Revised : 23-12-2014 } \\
\text { Accepted : 27-12-2014 } \\
\text { Keywords: } \\
\text { Calyx } \\
\text { Cost } \\
\text { Net gain } \\
\text { Benefit cost ratio } \\
{ }^{*} \text { Corresponding Author: } \\
\text { Tamirat Girma } \\
\text { E-mail: } \\
\text { tamirat.girma@yahoo.com }\end{array}$ \\
\hline
\end{tabular}

\section{INTRODUCTION}

Medicinal and aromatic plants (MAPs) are receiving considerable attention all over the world because of their vast untapped economic potential, especially in the use of herbal medicines. MAPs offer a wide range of safe and cost-effective, preventive and curative therapies, which are useful in achieving the goal of 'health for all' (Rashi Mittal and Singh, 2007).

Medicinal and Aromatic plant production in Ethiopia for commercial purpose is in its infant stage. Uses of these medicinal and aromatic crops are not well recognized and have got little consideration to undertake the production for commercial purpose. Hence the production of these crops is not significantly contributing to the countries growth and development. According to Endeshaw Bekele (2007), in Ethiopia, except in a few cases where a few food crops with medicinal value are cultivated, there is no organized cultivation of plants species for medicinal purposes. The reason for this is that the quantities of medicinal plants traded are very small, and there was no organized large scale value addition and processing.

However, in recent years some cooperatives are emerging which have been producing and supplying essential oils and herbs for domestic and in some amount for foreign market. Among these cooperatives Tabor essential oil PLC, Ariti Herbal PLC, Abyssinia Essential Oils PLC, Fana Medicinal and Aromatic Plants Growers Association, Sembero and Dawe Medicinal and Aromatic
Plant Growers Association, Herbal World PLC, Green Mark Herbs, Thyme Agrotech PLC, S\&P Energy Solutions PLC, AVT International Plc, Zifo Agri- Tech PLC are some of them. This is because of increasing demand for organic aromatic and medicinal plant products. For instance, in Ethiopia up to $80 \%$ of the population uses traditional medicine due to the cultural acceptability of healers and local pharmacopeias, the relatively low cost of traditional medicine and difficult access to modern health facilities (Kebede Deribe et al., 2006).

Roselle (Hibiscus sabdariffa L.) belongs to the family Malvaceae, locally called "karkade", is an important annual crop grown successfully in tropical and subtropical climates (Mohamed et al., 2012). Hibiscus sabdariffa is a deep-rooted crop, therefore deep plowing is recommended in preparing the seedbed. To produce a large calyx 1,000-2,000 pounds of manure are added per acre (1-2 tonnes/ha). Seeds are planted at a rate of 6-8 pounds or less per acre (6-8 kg/ha) and approximately one inch $(2.5 \mathrm{~cm})$ deep. Seeds are usually planted in the spring at the beginning of the rainy season (FAO, 2004).

It takes five months from planting to harvesting; it can also be regarded as a perennial Species grown for their fiber are tall, with fewer branches, sometimes growing to more than 3-5 $\mathrm{m}$ in height (Mohamed et al., 2012). 
Tamirat Girma et alo,

\section{Uses of Hibiscus}

The commercially important part of Hibiscus is the fleshy calyx (sepals) surrounding the fruit (capsules). The whole plant can be used as beverage, or the dried calyces can be soaked in water to prepare a colorful cold drink, or may be boiled in water and taken as a hot drink. It also has some medicinal properties (Mohamed et al., 2012).

The steam of the plant is used for fodder and fiber. In China the seeds are used for their oil and the plant is used for medicinal properties, and in West Africa the leaves and powdered seeds are a local foodstuff (FAO, 2004).

Hypertension decreasing effect of hibiscus is being reported on many studies. According to (Bako et al., 2010) the aqueous seed extract Hibiscus sabdariffa $L$. showed blood pressure lowering effect in normotensive cat with significant statistical difference $(P<0.05)$.
Sci. Technol. Arts Res. J., Oct-Dec 2014, 3(4): 214-218

According to this report, it is revealed that blood pressure (systolic and diastolic), pulse pressure and mean arterial pressure in all the three doses $(0.5,1.0$ and $5.0 \mathrm{mg} / \mathrm{ml}$ ) of seed extract which was set on the experiment decreased significantly $(P<0.05)$ when compare to normal basal rhythm, except in $5 \mathrm{mg} / \mathrm{ml}$ of the pulse pressure.

\section{Opportunities of the Production}

World Demand for hibiscus calyx has been increasing from time to time. According to FAO (2004), the main importers of hibiscus calyx in the world were USA and Germen. Table. 1 and chart. 1 revealed that amount and price of hibiscus calyx imported by the two countries was increased from first year to the next year. This indicates that that the demand of hibiscus calyx is increasing in the world from year to year.

Table1: US and Germany imports of plants and plant parts for use in herbal teas (tones)

\begin{tabular}{|c|c|c|c|c|c|c|c|}
\hline \multirow{2}{*}{$\begin{array}{l}\text { Countries the plant } \\
\text { imported from }\end{array}$} & \multicolumn{3}{|c|}{ Germany } & \multirow[t]{2}{*}{$\begin{array}{c}\text { Countries the plant } \\
\text { imported from }\end{array}$} & \multicolumn{3}{|c|}{ USA } \\
\hline & 1995 GC & 1996 GC & 1997 GC & & 1995 GC & 1996 GC & 1997 GC \\
\hline Bulgarie & 3,890 & 3,641 & 5,605 & China & 1,692 & 1,639 & 1,760 \\
\hline Poland & 1,761 & 2,879 & 4,684 & Mexico & 354 & 629 & 669 \\
\hline India & 5,993 & 5,588 & 4,456 & Chile & 395 & 333 & 629 \\
\hline Sudan & 3,005 & 2,557 & 3,157 & Germany & 433 & 396 & 326 \\
\hline Chile & 2,378 & 3,099 & 2,902 & India & 203 & 173 & 200 \\
\hline Egypt & 1,637 & 1,881 & 2,646 & Thailand & 223 & 163 & 154 \\
\hline US & 1,073 & 1,087 & 2,138 & Peru & 86 & 26 & 148 \\
\hline Hungary & 3,153 & 2,574 & 1,844 & Spain & 53 & 93 & 99 \\
\hline China & 1,661 & 1,701 & 1,821 & Canada & 3 & 3 & 98 \\
\hline Albania & 1,373 & 1,897 & 1,487 & S. Korea & 24 & 28 & 88 \\
\hline Argentina & 1,665 & 932 & 1,399 & Egypt & 79 & 106 & 54 \\
\hline Austria & 1,360 & 544 & 952 & Sudan & - & - & - \\
\hline Turkey & 608 & 817 & 820 & Other & 860 & 1,488 & 958 \\
\hline Brazil & 477 & 551 & 600 & - & - & - & - \\
\hline Australia & 168 & 560 & 542 & - & - & - & - \\
\hline Thailand & 366 & 358 & 422 & - & - & - & - \\
\hline Mexico & 104 & 354 & 200 & - & - & - & - \\
\hline Other & 7,237 & 7,311 & 7,160 & - & - & - & - \\
\hline TOTAL & 37,909 & 38,331 & 42,835 & TOTAL & 4,405 & 5,077 & 5,183 \\
\hline
\end{tabular}

Source: FAO, 2004

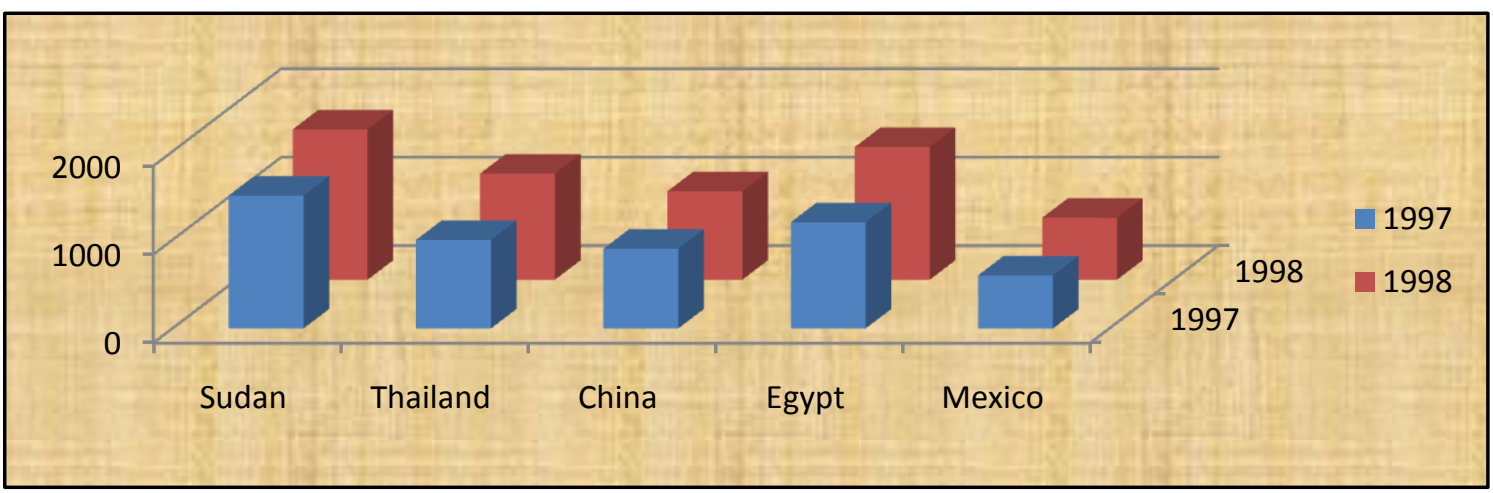

Figure 1: Price ranges for dried hibiscus calyx (US\$ per ton), 1997-1998 (Source: FAO, 2004)

However the demand for hibiscus calyx is high, the supply is not well developed; only Agriceft Private limited company, Ariti herbal private limited company and other petty traders are supplying hibiscus calyx for super markets in Ethiopia.

The farmer's holding small land can grow this crop in rotation or as intercrop with fruits and deep rooted crops to enhance per unit area return. It is also suitable for cultivation in water stressed conditions and as crops in orchard thus ensuring optimal use of the available land and to increase economic advantage of the growers.

\section{Challenges}

As indicated in different literature production of hibiscus calyx has some challenges. According to FAO, 2005 report major diseases of hibiscus are mostly stem and root rot. Recommended prevention technique include 
Tamirat Girma et alo,

monitoring water in an irrigated field as well as avoiding planting of crops that are prone to these diseases. Damage done to hibiscus by insects is minor but it does exist. Pests include the stem borer, flea beetles, abutilon moth, cotton bollworm, and the cutworm. Mealy bugs and the leafhoppers are minor concerns, as is the cotton strainer (Mohamed et al., 2012).

In Ethiopia, importance of hibiscus calyx is not well recognized, so there are no specific agencies dealing with seed production and distribution. But Wondo Genet Agriculture Research center as mandated on aromatic, medicinal and bio fuel plants research supplies basic seed for investors.

Objectives of the study were to examine financial feasibility of Hibiscus sabdariffa production at Wondo Genet and to determine associated costs and benefits from the production of hibiscus sabdariffa.

\section{MATERIALS AND METHODS}

\section{Description of the Study Area}

The study was conducted at Wondo Genet agricultural Research Center wendo genet research site; it is located about $268 \mathrm{~km}$ south of Addis Ababa and $14 \mathrm{~km}$ south east of shashemene. Wendo Genet Agricultural Research Center is geographically located at $07^{\circ} 03^{\prime} 19.1^{\prime \prime}$ to $07^{\circ}$ $04^{\prime} 00.2^{\prime \prime}$ North latitude and from $38^{\circ} 30^{\prime} 08.4^{\prime \prime}$ to $38^{\circ} 31^{\prime}$ $01.8^{\prime \prime}$ East longitude. The site receives mean annual rain fall of $1128 \mathrm{~mm}$ with minimum and maximum temperature of 11 and $26^{\circ} \mathrm{C}$, respectively. The soil textural class of the experimental area is sandy loam with $\mathrm{pH}$ of 6.4 (Zewdinesh Damtew et al., 2011).

\section{Experimental Procedure}

Two varieties of Hibiscus sabdariffa (Jamaican hibiscus and Sudan hibiscus) was planted on an area of $100 \mathrm{~m}^{2}$ on experimental field with two replications using direct sawing on the field and preparing seedlings on nursery for determination of costs and returns. The spacing between plants and between rows was $60 \mathrm{~cm}$ $(60 \mathrm{~cm}$ by $60 \mathrm{~cm})$. The amount of labor cost for land preparation, planting, watering, weeding and hoeing, chemical application and harvesting operations and cost of fertilizer, planting material, and plowing was recorded by intensive follow up using field books. In addition to this, yields per each harvesting cycle were recorded. Even if the market for this plant product was not well established the price data was collected through telephone interview
Sci. Technol. Arts Res. J., Oct-Dec 2014, 3(4): 214-218

from different places. Moreover, international journals, Publications and web sites were used as required to determine selling price.

\section{Data Analysis}

Simple cost accounting method was employed to examine cost benefit of the plant. Cost and Yield data collected from experimental field was recorded on field book and entered to MS- excel for analysis. Generally after collected data entered to MS-excel, these data was changed to hectare values using changing factors. Total cost of the production is calculated and the revenue that can be produced was determined using market price to determine the net benefit and BCR of hibiscus production. Visual observation and follow up for disease symptom was carried out by pathologists and entomologists during its life time to compare with what was reported on hibiscus producing countries report.

\section{RESULT AND DISCUSSION}

\section{Jamaican Type of Hibiscus}

As illustrated in table 2 and 5 about near to $40 \%$ of production cost of hibiscus by seedling preparation is nursery management cost. This includes cost of plastic pot and labor cost for planting in pot, watering, weeding and transplanting.

Using direct sawing seed of hibiscus on the field, largest cost incurring activity is harvesting and post harvest management. This is due to indeterminate maturing nature of the plant, and harvesting need to be frequent as the calyx mature. Never the less the difference shown in table 2 for the two way of production in cost of harvesting and post harvest management is caused by amount of calyx yield collected from each plot. The result of this study (table 2) shows in direct sowing share of costs are $62 \%, 11.8 \%, 9.5 \%$, and $0.4 \%$ for harvesting and post harvest management, labor cost for irrigation, land preparation and planting and seed cost respectively.

Cost of nursery management has a largest cost share $(40.7 \%)$ in production of hibiscus if seedling is prepared on nursery. Harvesting and post harvesting management, land preparation and planting cost, labor cost for irrigation, chemical(pesticide) cost and seed cost are part of expenses respectively following nursery management cost

Table 2: production cost of Jamaican hibiscus by direct sawing on the field and by preparing seedlings

\begin{tabular}{|c|c|c|c|c|c|c|}
\hline \multirow[b]{2}{*}{ Activities } & \multicolumn{3}{|c|}{ By sawing the seed on field } & \multicolumn{3}{|c|}{ By preparing seedlings on nursery } \\
\hline & $\begin{array}{l}\text { Total cost } \\
\text { per plot } \\
\text { (In US \$) }\end{array}$ & $\begin{array}{c}\text { Total cost } \\
\text { per hectare } \\
\text { (In US \$) }\end{array}$ & $\%$ & $\begin{array}{l}\text { Total cost } \\
\text { per plot } \\
\text { (In US \$) }\end{array}$ & $\begin{array}{l}\text { Total cost per } \\
\text { hectare (In US } \\
\$)\end{array}$ & $\%$ \\
\hline Seed cost & 0.082 & 8.15 & 0.4 & 0.082 & 8.15 & 0.5 \\
\hline Nursery management cost & 0.000 & 0.00 & 0 & 6.417 & 641.67 & 40.7 \\
\hline Land preparation and planting cost & 2.078 & 207.75 & 9.5 & 2.078 & 207.75 & 13.2 \\
\hline Labor cost for irrigation & 2.592 & 259.18 & 11.8 & 1.102 & 110.22 & 7 \\
\hline Labor cost for weeding and hoeing & 1.575 & 157.52 & 7.2 & 1.424 & 142.43 & 9 \\
\hline Harvesting and post harvest management cost & 13.588 & 1358.83 & 62 & 2.655 & 265.48 & 16.9 \\
\hline Chemical (pesticide) cost & 0.000 & 0.00 & 0 & 0.566 & 56.62 & 3.6 \\
\hline Total cost & 19.914 & 1991.44 & & 14.323 & 1432.31 & \\
\hline Miscellaneous cost (10\%) & 1.991 & 199.14 & & 1.432 & 143.23 & \\
\hline Overall cost & 21.906 & $2,190.59$ & & 15.755 & $1,575.54$ & \\
\hline
\end{tabular}


Table 3: Yield and net benefit of production of Jamaican hibiscus by direct sawing on the field

\begin{tabular}{|c|c|c|c|c|c|c|c|c|c|c|}
\hline $\begin{array}{l}\text { Harvesting } \\
\text { cycle }\end{array}$ & $\begin{array}{c}\text { Dry } \\
\text { calyx } \\
\text { yield } \\
\text { /ha(Kg) }\end{array}$ & $\begin{array}{c}\text { Unit } \\
\text { price } \\
\text { of dry } \\
\text { calyx } \\
/ \mathrm{Kg} \\
\text { (in \$) }\end{array}$ & $\begin{array}{c}\text { Total } \\
\text { gain } \\
\text { from } \\
\text { calyx } \\
\text { /ha } \\
\text { (in \$) }\end{array}$ & $\begin{array}{l}\text { Yield of } \\
\text { dry } \\
\text { seed/ha } \\
(\mathrm{Kg})\end{array}$ & $\begin{array}{c}\text { Unit } \\
\text { price } \\
\text { of dry } \\
\text { seed } \\
\text { (Kg) } \\
\text { (in \$) }\end{array}$ & $\begin{array}{c}\text { Total } \\
\text { gain } \\
\text { from } \\
\text { seed } \\
\text { /ha } \\
\text { (in \$) }\end{array}$ & $\begin{array}{c}\text { Total } \\
\text { gain /ha } \\
\text { (in \$) }\end{array}$ & $\begin{array}{c}\text { Total } \\
\text { cost per } \\
\text { hectare } \\
\text { (in \$) }\end{array}$ & $\begin{array}{l}\text { Net gain } \\
\text { per } \\
\text { hectare } \\
\text { (in \$) }\end{array}$ & $\begin{array}{c}\text { Benefit } \\
\text { cost } \\
\text { ratio }\end{array}$ \\
\hline 1 & 101.23 & & & 140.45 & & & & & & \\
\hline 2 & 74.53 & & & 56.62 & & & & & & \\
\hline 3 & 103.64 & & & 90.04 & & & & & & \\
\hline 4 & 74.92 & & & 125.67 & & & & & & \\
\hline 5 & 136.22 & & & 165.59 & & & & & & \\
\hline 6 & 122.15 & & & 306.13 & & & & & & \\
\hline 7 & 309.49 & & & 668.2 & & & & & & \\
\hline 8 & 179.77 & & & 387.62 & & & & & & \\
\hline Total & 1101.95 & 6.04 & 6654.96 & 1940.32 & 0 & 0 & 6654.96 & $2,190.59$ & 4464.37 & 3.04 \\
\hline
\end{tabular}

Table 4: Yield and net benefit of production of Jamaican hibiscus by seedling preparation on nursery

\begin{tabular}{|c|c|c|c|c|c|c|c|c|c|c|}
\hline $\begin{array}{l}\text { Harvesting } \\
\text { cycle }\end{array}$ & $\begin{array}{c}\text { Dry } \\
\text { calyx } \\
\text { yield/ha } \\
(\mathrm{Kg})\end{array}$ & $\begin{array}{l}\text { Unit } \\
\text { price of } \\
\text { dry } \\
\text { calyx/Kg } \\
\text { (in \$) }\end{array}$ & $\begin{array}{l}\text { Total } \\
\text { gain } \\
\text { from } \\
\text { calyx/ha } \\
\text { (in \$) }\end{array}$ & $\begin{array}{c}\text { Yield of } \\
\text { dry } \\
\text { seed/ha } \\
(\mathrm{Kg})\end{array}$ & $\begin{array}{c}\text { Unit } \\
\text { price } \\
\text { of } \\
\text { dry } \\
\text { seed } \\
\text { (Kg) } \\
\text { (in \$) }\end{array}$ & $\begin{array}{l}\text { Total } \\
\text { gain } \\
\text { from } \\
\text { seed/ha } \\
\text { (in \$) }\end{array}$ & $\begin{array}{l}\text { Total } \\
\text { gain /ha } \\
\text { (in \$) }\end{array}$ & $\begin{array}{l}\text { Total } \\
\text { cost per } \\
\text { hectare } \\
\text { (in \$) }\end{array}$ & $\begin{array}{c}\text { Net } \\
\text { gain } \\
\text { per } \\
\text { hectare } \\
\text { (in \$) }\end{array}$ & $\begin{array}{c}\text { Benefit } \\
\text { cost } \\
\text { ratio }\end{array}$ \\
\hline 1 & 27 & & & 15.19 & & & & & & \\
\hline 2 & 42.46 & & & 138.03 & & & & & & \\
\hline 3 & 121 & & & 194.76 & & & & & & \\
\hline 4 & 80.35 & & & 249.15 & & & & & & \\
\hline Total & 270.81 & 6.04 & $1,635.69$ & 597.13 & 0 & 0 & $1,635.69$ & $1,575.54$ & 60.15 & 1.04 \\
\hline
\end{tabular}

Jamaican type of hibiscus is more profitable in direct sawing than raising seedlings on nursery; this is because of costs associated with nursery management.

As indicated in table 3 production of this plant by direct sawing on the field can produce more calyx $(1101.95 \mathrm{~kg})$ and seed (1940.32 kg) than producing by seedling preparation on nursery (table 4 ) which can produce about $270.8 \mathrm{~kg}$ calyx and $597.13 \mathrm{~kg}$ hibiscus seed. More over benefit cost ratio(BCR) in direct sawing (table 3 ) indicates by far better benefit i.e. net return obtained is about 2.04 fold of the expense of the production; while 0.04 fold if it was done by preparing seedlings on nursery.

\section{Sudan type of Hibiscus sabdariffa}

Table 5 shows that about $63.6 \%$ of production cost in direct sawing is for harvesting and post harvest management; where the other accounts about $36.4 \%$ which is less than half of total cost of production. Nursery management cost is the highest costly activity if produced by seedling preparation which accounts about $39.7 \%$ of total production cost.

Table 5: production cost of Sudan hibiscus by direct sawing on the field and by preparing seedlings

\begin{tabular}{|c|c|c|c|c|c|c|}
\hline \multirow[b]{2}{*}{ Activities } & \multicolumn{3}{|c|}{ By sawing the seed on field } & \multicolumn{3}{|c|}{ By preparing seedlings on nursery } \\
\hline & $\begin{array}{l}\text { Total cost } \\
\text { per plot } \\
\text { (In US \$) }\end{array}$ & $\begin{array}{l}\text { Total cost per } \\
\text { hectare } \\
\text { (In US \$) }\end{array}$ & $\%$ & $\begin{array}{l}\text { Total cost } \\
\text { per plot } \\
\text { (In US \$) }\end{array}$ & $\begin{array}{c}\text { Total cost per } \\
\text { hectare (In US } \$ \text { ) }\end{array}$ & $\%$ \\
\hline Seed cost & 0.082 & 8.15 & 0.4 & 0.082 & 8.15 & 0.5 \\
\hline Nursery management cost & 0.000 & 0.00 & 0 & 6.417 & 641.67 & 39.7 \\
\hline land preparation and planting cost & 2.078 & 207.75 & 9 & 2.078 & 207.75 & 12.9 \\
\hline labor cost for irrigation & 2.592 & 259.18 & 11.2 & 1.102 & 110.22 & 6.8 \\
\hline labor cost for weeding and hoeing & 1.575 & 157.52 & 6.8 & 1.424 & 142.43 & 8.8 \\
\hline $\begin{array}{l}\text { harvesting and post harvest } \\
\text { management cost }\end{array}$ & 14.721 & 1472.07 & 63.6 & 3.020 & 301.96 & 18.7 \\
\hline Chemical (pesticide) cost & 0.000 & 0.00 & 0 & 0.566 & 56.62 & 3.5 \\
\hline Total cost & 21.047 & 2104.68 & & 14.688 & 1468.80 & \\
\hline Miscellaneous cost (10\%) & 2.105 & 210.47 & & 1.469 & 146.88 & \\
\hline Overall cost & 23.151 & $2,315.15$ & & 16.157 & $1,615.68$ & \\
\hline
\end{tabular}


Table 6: Yield and net benefit of production of Sudan hibiscus by direct sawing on the field

\begin{tabular}{|c|c|c|c|c|c|c|c|c|c|c|}
\hline $\begin{array}{l}\text { Harvesting } \\
\text { cycle }\end{array}$ & $\begin{array}{l}\text { Dry } \\
\text { calyx } \\
\text { yield } \\
\text { /ha } \\
(\mathrm{Kg})\end{array}$ & $\begin{array}{c}\text { Unit } \\
\text { price of } \\
\text { dry } \\
\text { calyx/Kg } \\
\text { (in \$) }\end{array}$ & $\begin{array}{l}\text { Total } \\
\text { gain } \\
\text { from } \\
\text { calyx } \\
\text { /ha } \\
\text { (in \$) }\end{array}$ & $\begin{array}{l}\text { Yield of } \\
\text { dry } \\
\text { seed/ha } \\
(\mathrm{Kg})\end{array}$ & $\begin{array}{c}\text { Unit } \\
\text { price of } \\
\text { dry } \\
\text { seed } \\
(\mathrm{Kg}) \text { (in } \\
\text { \$) }\end{array}$ & $\begin{array}{l}\text { Total } \\
\text { gain } \\
\text { from } \\
\text { seed/ha } \\
\text { (in \$) }\end{array}$ & $\begin{array}{l}\text { Total } \\
\text { gain /ha } \\
\text { (in \$) }\end{array}$ & $\begin{array}{l}\text { Total } \\
\text { cost per } \\
\text { hectare } \\
\text { (in \$) }\end{array}$ & $\begin{array}{c}\text { Net } \\
\text { gain } \\
\text { per } \\
\text { hectare } \\
\text { (in \$) }\end{array}$ & $\begin{array}{l}\text { Benefit } \\
\text { cost } \\
\text { ratio }\end{array}$ \\
\hline $\begin{array}{l}1 \\
2 \\
3\end{array}$ & $\begin{array}{c}215 \\
397.5 \\
619\end{array}$ & & & $\begin{array}{c}93.5 \\
172.9 \\
414\end{array}$ & & & & & & \\
\hline Total & 1231.5 & 6.04 & $7,438.26$ & 680.4 & 0 & 0 & $7,438.26$ & $2,315.15$ & 5123.11 & 3.21 \\
\hline
\end{tabular}

Table 7: Yield and net benefit of production of Sudan hibiscus by seedling preparation on nursery

\begin{tabular}{|c|c|c|c|c|c|c|c|c|c|c|}
\hline $\begin{array}{l}\text { Harvesting } \\
\text { cycle }\end{array}$ & $\begin{array}{c}\text { Dry } \\
\text { calyx } \\
\text { yield/ } \\
\text { ha } \\
(\mathrm{Kg})\end{array}$ & $\begin{array}{l}\text { Unit price } \\
\text { of dry } \\
\text { calyx } / \mathrm{Kg} \\
\text { (in \$) }\end{array}$ & $\begin{array}{l}\text { Total } \\
\text { gain } \\
\text { from } \\
\text { calyx } \\
\text { /ha } \\
\text { (in \$) }\end{array}$ & $\begin{array}{c}\text { Yield } \\
\text { of dry } \\
\text { seed } \\
\text { /ha } \\
(\mathrm{Kg})\end{array}$ & $\begin{array}{c}\text { Unit } \\
\text { price } \\
\text { of dry } \\
\text { seed } \\
(\mathrm{Kg}) \\
\text { (in \$) }\end{array}$ & $\begin{array}{l}\text { Total } \\
\text { gain } \\
\text { from } \\
\text { seed/ha } \\
\text { (in \$) }\end{array}$ & $\begin{array}{l}\text { Total } \\
\text { gain } \\
\text { /ha } \\
\text { (in \$) }\end{array}$ & $\begin{array}{l}\text { Total } \\
\text { cost per } \\
\text { hectare } \\
\text { (in \$) }\end{array}$ & $\begin{array}{l}\text { Net gain } \\
\text { per } \\
\text { hectare } \\
\text { (in \$) }\end{array}$ & $\begin{array}{c}\text { Benefit } \\
\text { cost } \\
\text { ratio }\end{array}$ \\
\hline 1 & 51.1 & & & 27.56 & & & 0 & & & \\
\hline 2 & 102.02 & & & 55.024 & & & & & & \\
\hline 3 & 154.75 & & & 128.34 & & & 0 & & & \\
\hline Total & 307.87 & 6.04 & $1,859.5$ & 210.92 & 0 & 0 & $1,859.5$ & $1,615.68$ & 243.82 & 1.15 \\
\hline
\end{tabular}

Table 6 and 7 shows that producing Sudan type of hibiscus is profitable both by direct sawing seed on the field and by preparing seedlings on nursery. Similar to production of Jamaican type of hibiscus, producing Sudan type of hibiscus by direct sawing the seed on the field is more profitable as indicated in table 6 by benefit cost ratio $(\mathrm{BCR}=3.21)$ than producing by preparing seedlings on nursery $(B C R=1.15)$.

\section{CONCLUSION}

Production cost of Sudan type hibiscus is almost similar to Jamaican type except harvesting and post harvesting management cost difference caused due to yield difference. However the production of Sudan hibiscus is more profitable by both direct sawing and seedling preparation on nursery; the study indicated that producing both type of hibiscus for calyx yield by direct sawing is more profitable.

As it is shown in the yield tables (table 6 and 7) Sudan type of hibiscus reaches for harvest more uniformly than Jamaican type but needs more time to dry the calyx due to thickness of the calyx which leads to more costs. However seed of hibiscus is used for animal feed in different countries, this is not practical in Ethiopia.

To make use of increasing world demand of hibiscus calyx, concerned government bodies should popularize the opportunity for foreign and domestic investors. Ethiopian trade and industry minister should take its part in strengthening market channel of hibiscus calyx so as to create sustainable production and to benefit small holder farmers

\section{REFERENCES}

Bahaeldeen Babiker Mohamed., Abdelatif Ahmed Sulaiman and Abdelhafiz Adam Dahab (2012). Roselle (Hibiscus sabdariffa L.) in Sudan, Cultivation and Their Uses. Bulletin of Environment, Pharmacology and Life Sciences 1(6): 48-54

Endeshaw Bekele (2007). Study on Actual Situation of Medicinal Plants in Ethiopia. Japan Association for International Collaboration of Agriculture and Forestry. http://www.jaicaf.or.jp/publications/ethiopia_ac.pdf

FAO, (2004) HIBISCUS: Post-Production Management for Improved Market Access. http://www.fao.org/fileadmin/ user_upload/inpho/docs/Post_Harvest_Compendium__Hibiscus.pdf

Bako, I.G. Mabrouk, M.A., Maje, I.M., Buraimoh A.A and Abubakar, M.S. (2010) Hypotensive Effect of Aqueous Seed Extract of Hibiscus sabdariffa linn (Malvaceae) on Normotensive Cat. International Journal of Animal Sciences and Veterinary Advances 2(1): 5-8.

Kebede Deribe Kassaye., Alemayehu Amberbir., Binyam Getachew., Yunis Mussema. (2006). A historical overview of traditional medicine practices and policy in Ethiopia. Ethiopian Journal of Health Development 20(2):127-134.

Rashi Mittal and Singh, S.P. (2007). Shifting from Agriculture to Agribusiness: The Case of Aromatic Plants. Agricultural Economics Research Review 20:541-550.

Yadong Qi., Kit L. Chin., Fatemah Malekian., Mila Berhane. and Janet Gager (2005). Biological Characteristics, Nutritional and Medicinal Value of Roselle, Hibiscus Sabdariffa. Circular UFNR- Urban Forestry Natural Resources and Environment, No.604,

Zewdinesh Damtew., Bizuayehu Tesfaye., Daniel Bisrat. (2011). Leaf, Essential Oil and Artemisinin Yield of Artemisia (Artemisia annua L.) As Influenced by Harvesting Age and Plant Population Density. World Journal of Agricultural Sciences 7(4): 404-412. 